\title{
LPS-binding Protein Protects Mice from Septic Shock Caused by LPS or Gram-negative Bacteria
}

\author{
Norbert Lamping, Rudolf Dettmer, Nicolas W.J. Schröder, Dagmar Pfeil, Werner Hallatschek, Reinhard Burger, ${ }^{*}$ \\ and Ralf R. Schumann \\ Institut für Mikrobiologie und Hygiene, Universitätsklinikum Charité, Medizinische Fakultät der Humboldt-Universität zu Berlin, \\ D-10098, Berlin, Germany; and *Robert-Koch-Institut, D-13353 Berlin, Germany
}

\begin{abstract}
LPS-binding protein (LBP) recognizes bacterial LPS and transfers it to CD14, thereby enhancing host cell stimulation, eventually resulting in pathogenic states such as septic shock. Recently, LBP also was shown to detoxify LPS by transferring LPS into HDL particles in vitro. Thus, the predominant in vivo function of LBP has remained unclear. To investigate the biological activity of acute phase concentrations of recombinant murine LBP, high concentrations of LBP were investigated in vitro and in vivo. Although addition of low concentrations of LBP to a murine macrophage cell line enhanced LPS-induced TNF- $\alpha$ synthesis, acute phase concentrations of LBP blocked this effect in comparison to low-dose LBP. When injected into mice intraperitoneally, LBP inhibited LPS-mediated cytokine release and prevented hepatic failure resulting in a significantly decreased mortality rate in LPS-challenged and D-galactosamine-sensitized mice, as well as in a murine model of bacteremia. These results complement a recent study revealing LBP-deficient mice to be dramatically more susceptible to an intraperitoneal Salmonella infection as compared with normal mice. We conclude that acute phase LBP has a protective effect against LPS and bacterial infection and may represent a physiologic defense mechanism against infection. Despite the limitations of any murine sepsis model, the results shown may imply that LBP could have beneficial effects during gram-negative peritonitis in humans. (J. Clin. Invest. 1998. 101:2065-2071.) Key words: lipopolysaccharides • antagonist and inhibitors - gram-negative bacterial infection • septic shock therapy • macrophage activation
\end{abstract}

\section{Introduction}

Infection or trauma can lead to sepsis or the systemic inflammatory response syndrome, respectively, representing severe clinical syndromes characterized by cytokine release, increased expression of adhesion molecules, chemotactic recruit-

Address correspondence to Ralf R. Schumann, M.D., Institut für Mikrobiologie und Hygiene, Universitätsklinikum Charité, Medizinische Fakultät der Humboldt-Universität zu Berlin, Dorotheenstr. 96-98, D-10098 Berlin, Germany. Phone: 49-30-2093-4747; FAX: 4930-2093-4704; E-mail: rschuman@charite.de

Received for publication 24 November 1997 and accepted in revised form 8 March 1998.

J. Clin. Invest.

(C) The American Society for Clinical Investigation, Inc. 0021-9738/98/05/2065/07 \$2.00

Volume 101, Number 10, May 1998, 2065-2071

http://www.jci.org ment of lymphoid cells, increased phagocytotic activity of macrophages, release of reactive oxygen species, and expression of acute phase proteins (1-3). This cascade of events may eventually lead to life-threatening complications including multiple organ failure and a decrease in blood pressure resulting in shock $(4,5)$. Recent reports calculate that 100,000-300,000 deaths in the United States are caused annually by sepsis (6). LPS, a constituent of the outer membrane of gram-negative bacteria, apparently is one of the major toxins responsible for initiating this pathophysiological cascade (7-10). In addition to cases caused directly by gram-negative microorganisms (accounting for $30-40 \%$ ) in bacteremia involving gram-positive bacteria or in systemic inflammatory response syndrome, LPS may also play a pathogenic role due to bacterial translocation from the gut (11).

LPS-binding protein $(\mathrm{LBP})^{1}$ binds to $\operatorname{LPS}(12,13)$ and transfers it to the LPS receptor CD14 (14-17) and into HDL $(12,18)$. LPS-mediated stimulation of CD14-positive cells is enhanced 100-1,000-fold when LBP is added to serum-free systems and therefore LBP has been thought to participate in the pathogenesis of septic shock $(19,20)$. LBP was first detected in rabbits, where serum levels are relatively low as compared with other species, including mice and humans. Therefore, concentrations of $100 \mathrm{ng} / \mathrm{ml}$ were used in a series of initial studies examining the in vitro function of LBP, all demonstrating LPS-enhancing activities of LBP. However, humans exhibit higher constitutive levels of LBP of 5-15 $\mu \mathrm{g} / \mathrm{ml}(21-23)$. Furthermore, we have shown by promoter analysis studies that the LBP gene is transcriptionally activated during the acute phase response (24), and acute phase serum levels of LBP during sepsis, consistent with these studies, are clearly elevated reaching peak levels of up to $200 \mu \mathrm{g} / \mathrm{ml}$ (23). LBP can be detected in several body fluids including peritoneal exudate, and in peritonitis LBP concentrations approach those in plasma and are increased 3-10-fold as compared with noninfected individuals $(25,26)$. In mice, as we show here, constitutive LBP levels are also in the microgram per milliliter range and the acute phase response leads to fivefold elevated serum levels of LBP. It has remained unclear why the host organism upregulates expression and synthesis of a protein that until now was thought to enhance LPS effects potentially leading to sepsis.

Previous results have shown that LBP is also able to mediate binding of LPS to membrane CD14 and subsequent internalization of LPS without cell stimulation (27). It was demonstrated that LBP not only mediates binding of LPS to CD14, but also binding of whole gram-negative bacteria to CD14 leading to phagocytosis and subsequent clearance of bacteria

1. Abbreviations used in this paper: ALT, alanine aminotransferase; GST, glutathione $s$-transferase; LBP, LPS-binding protein; LDH, lactate dehydrogenase; mLBP, murine LBP. 
$(28,29)$. Additionally, LBP was found to mediate LPS transfer to reconstituted HDL, attenuating its stimulatory effects (12, 18). HDL-bound LPS lacks cell stimulatory activity and reconstituted HDL in vitro and in vivo inhibits the toxic effects of LPS (30-32). Because of these potentially conflicting results the primary in vivo function of LBP has remained controversial, as has the question of whether the acute phase rise of LBP is a protective measure, or enhances the inflammatory cascade triggered by LPS. Despite the large number of in vitro studies showing that addition of LBP to serum-free systems enhances LPS effects, no experiments have been reported using high concentrations of LBP comparable to those observed in septic patients. Neither have there been any in vivo animal studies using recombinant LBP in the context of experimental sepsis. Furthermore, LBP-deficient mice are not suitable to differentiate between the roles of low constitutive versus high acute phase LBP levels $(33,34)$. In the study presented here we describe the in vitro and in vivo effects of high-dose recombinant murine LBP (mLBP). In vitro, high concentrations of LBP surprisingly blocked the LPS-induced stimulation of a murine macrophage cell line, both in the absence and in the presence of murine serum. In addition, LBP inhibited LPS-mediated secretion of cytokines in mice sensitized with D-galactosamine and decreased LPS-induced hepatic failure. Finally, when injected with LBP, mice survived an otherwise lethal challenge with LPS or live bacteria.

\section{Methods}

Construction of the LBP expression vector. The cDNA of mLBP (kindly provided by D. Heumann, Lausanne, Switzerland) was amplified by PCR using primers generating a XhoI site at the $5^{\prime}$ and a BgIII site at the $3^{\prime}$-end. Using these restriction sites, the mLBP cDNA was inserted into the baculovirus expression vector pAcGHLT-B (PharMingen, Hamburg, Germany) containing the glutathione $s$-transferase (GST) gene for purification of the resulting fusion protein. The mLBP cDNA lacking the signal sequence was cloned behind the GST gene leading to the mLBP-pAcGHLT-B vector.

Expression and purification of $m L B P-G S T$ fusion protein. Sf-9 insect cells were cotransfected with BaculoGold baculovirus DNA (PharMingen) and the mLBP-pAcGHLT-B vector using lipofectamine (Gibco, Eggenstein, Germany). Cells were grown in EX-CELL 401 medium (Biozol, Eching, Germany) containing 10\% FCS and antibiotics. Sf-9 insect cells were infected with recombinant baculovirus at a multiplicity of infection of $\sim 5$ viruses per insect cell, harvested after 3-4 d, washed with PBS, shock frozen in liquid nitrogen, and stored at $-70^{\circ} \mathrm{C}$. To purify GST-fusion protein, Sf- 9 cells were lysed for $45 \mathrm{~min}$ on ice with lysis buffer ( $10 \mathrm{mM}$ Tris, $\mathrm{pH} 7.5,130 \mathrm{mM} \mathrm{NaCl}, 1 \%$ Triton $\mathrm{X}-100,10 \mathrm{mM}$ NaF, $10 \mathrm{mM}$ NaPi, $10 \mathrm{mM} \mathrm{NaPPi}$ ) containing $16 \mu \mathrm{g} / \mathrm{ml}$ benzamidine $\mathrm{HCl}, 10 \mu \mathrm{g} / \mathrm{ml}$ phenantroline, $10 \mu \mathrm{g} / \mathrm{ml}$ aprotinin, $10 \mu \mathrm{g} /$ $\mathrm{ml}$ leupeptin, $10 \mu \mathrm{g} / \mathrm{ml}$ pepstatin A, and $1 \mathrm{mM}$ PMSF. After centrifugation of the lysate, GST-Sepharose 4B (Pharmacia Biotech GmbH, Freiburg, Germany) was added to the supernatant. The lysate was mixed for $90 \mathrm{~min}$ at $4^{\circ} \mathrm{C}$ on a rocking platform, followed by washing with PBS, $1 \mathrm{mM}$ DTT, and $0.1 \%$ Triton X-100. Then, the GSTSepharose was incubated with $6 \mathrm{U} / \mathrm{ml}$ of thrombin (ICN Biochemicals, Eschwege, Germany) for $45 \mathrm{~min}$ at $4^{\circ} \mathrm{C}$. Cleaved mLBP was released into the supernatant, and subsequently Triton X-100 was removed by incubating with Calbiosorb (Calbiochem, Bad Soden, Germany) overnight at $4^{\circ} \mathrm{C}$ on a rocking platform. Thrombin was removed using small quantities of Benzamidine-Sepharose 6B (Pharmacia Biotech $\mathrm{GmbH}$ ). The absence of Triton X-100 was monitored by measuring absorbance at $270 \mathrm{~nm}$, and thrombin activity was determined using a chromogenic thrombin assay according to a published protocol (35). Purity of mLBP was $>95 \%$ as confirmed by SDS-
PAGE and Coomassie blue staining. LPS contamination, determined by conventional Limulus assay (Labortechnik Peter Schulz, Munich, Germany), was $<0.3 \mathrm{pg}$ LPS $/ \mu \mathrm{g}$ mLBP.

Stimulation of RAW 264.7 cells using recombinant $m L B P$ and Escherichia coli O111:B4 LPS in the absence or presence of murine serum. $5 \times 10^{5}$ cells per well of the murine macrophage cell line RAW 264.7 cells (kindly provided by T. Blankenstein, MDC, Berlin, Germany) were grown in RPMI containing $10 \%$ FCS overnight in 96-well tissue culture plates. Subsequently, cells were washed with serumfree RPMI and stimulated with E. coli O111:B4 LPS (Sigma, Deisenhofen, Germany) and increasing concentrations of recombinant $\mathrm{mLBP}$ in the absence or presence of murine serum. After $4 \mathrm{~h}$, supernatants were harvested and stored at $-70^{\circ} \mathrm{C}$. As shown in Fig. 1, 10 $\mathrm{ng} / \mathrm{ml} \mathrm{mLBP}$ gave nearly maximal TNF- $\alpha$ response, and therefore $1 \%$ murine serum corresponding to $15 \mathrm{ng} / \mathrm{ml} \mathrm{mLBP}$ was used in a subsequent experiment. During gram-negative infection, LPS concentrations in the lower nanogram range are usually observed and therefore an LPS concentration of $330 \mathrm{pg} / \mathrm{ml}$ was chosen.

Cytotoxicity tests for mLBP towards RAW 264.7 cells. To exclude cytotoxic effects of high-dose mLBP towards RAW 264.7 cells, several experiments were performed. To determine viability of RAW 264.7 cells after exposure to $330 \mathrm{pg} / \mathrm{ml}$ LPS and $10 \mu \mathrm{g} / \mathrm{ml} \mathrm{mLBP}$ for $4 \mathrm{~h}$, trypan blue exclusion was assessed using light microscopy. In addition, the release of lactate dehydrogenase (LDH) activity indicating impaired cell membrane function was determined using a commercial LDH cytotoxicity assay (Boehringer-Mannheim, Mannheim, Germany) according to the manufacturer's instructions. Supernatant of RAW 264.7 cells stimulated for $4 \mathrm{~h}$ with $330 \mathrm{pg} / \mathrm{ml}$ LPS in the absence and presence of $10 \mu \mathrm{g} / \mathrm{ml} \mathrm{mLBP}$ was tested for LDH activity. As standard, serial dilutions of RAW 264.7 cell lysates prepared from a known number of cells were included. Additionally, PMA (Sigma), an LPS-independent stimulus for TNF- $\alpha$ synthesis, was added at a concentration of $50 \mathrm{ng} / \mathrm{ml}$ for $4 \mathrm{~h}$ to RAW 264.7 cells in the presence and absence of $10 \mu \mathrm{g} / \mathrm{ml} \mathrm{mLBP}$. Subsequently the amount of TNF- $\alpha$ synthesis was determined by ELISA in order to assess cellular function.

Induction of cytokine release and hepatic injury by LPS in D-galactosamine-sensitized mice. 10-14-wk-old female C57Bl/6 mice (Bomholtgaard, Ry, Denmark) were injected intraperitoneally with $20 \mathrm{mg}$ D-galactosamine, $2.5 \mathrm{ng}$ E. coli O111:B4 LPS, and $100 \mu \mathrm{g} \mathrm{mLBP}$ in a total volume of $400 \mu \mathrm{l}$. Three groups, each containing five animals, were injected with LPS and D-galactosamine; LPS, D-galactosamine, and $\mathrm{mLBP}$; or D-galactosamine and $\mathrm{mLBP} .75 \mathrm{~min}$ and $7 \mathrm{~h}$ after injection, animals were bled retroorbitally and the blood collected was allowed to clot for $1 \mathrm{~h}$ on ice, centrifuged, and the serum was stored in small aliquots at $-70^{\circ} \mathrm{C}$. For each subsequent determination of LBP, cytokines, or liver enzymes, fresh aliquots were thawed.

$m L B P$-ELISA. ELISA plates were coated with $10 \mu \mathrm{g} / \mathrm{ml}$ of purified polyclonal anti-mLBP antibody which was obtained by immunizing rabbits with purified recombinant mLBP. The resulting polyclonal antibody showed no cross-reactivity with bovine and human LBP but was highly cross-reactive with rat LBP. Samples and recombinant mLBP standard were detected using a biotin-labeled polyclonal rabbit anti-mLBP antibody at $5 \mu \mathrm{g} / \mathrm{ml}$. The detection limit of the ELISA is $25 \mathrm{pg} / \mathrm{ml}$.

Murine TNF- $\alpha$ and IL-6 ELISA. ELISA plates were coated with $5 \mu \mathrm{g} / \mathrm{ml}$ anti-mTNF mAb (Endogen, Boston, MA). Samples and recombinant mTNF standard (R\&D, Wiesbaden, Germany) were incubated and bound mTNF was detected using a polyclonal rabbit antimTNF- $\alpha$ antibody (Endogen, Boston, MA) at $10 \mu \mathrm{g} / \mathrm{ml}$. IL-6 levels were determined using a commercial cytokine ELISA kit (R\&D) according to the manufacturer's instructions.

Determination of hepatic injury by measurement of alanine aminotransferase (ALT) activity. Determination of ALT activity was carried out using a commercial kit for quantitative colorimetric determination of ALT (Sigma) according to the manufacturer's instructions.

Mortality of C57Bl/6 mice injected with D-galactosamine and LPS 
with or without $m L B P$, or with E. coli O111:B4 with or without $m L B P$. 10-14-wk-old female C57Bl/6 mice were injected intraperitoneally with $20 \mathrm{mg}$ D-galactosamine, $2.5 \mathrm{ng}$ E. coli O111:B4 LPS (Sigma), and $100 \mu \mathrm{g}$ recombinant mLBP, or control buffer, respectively, in a total volume of $400 \mu$ l. Mortality was assessed at 12, 24, and 36 h. E. coli O111:B4 bacteria (No. 33780; American Type Culture Collection, Rockville, MD) were grown at $37^{\circ} \mathrm{C}$, washed, and quantitated by measuring OD at $600 \mathrm{~nm}$. Additionally, C57B1/6 mice were injected intraperitoneally with $10^{7}$ colony-forming units of $E$. coli O111:B4 and $100 \mu \mathrm{g}$ recombinant $\mathrm{mLBP}$, or bacteria and control buffer, respectively, in a total volume of $500 \mu \mathrm{l}$. Mortality was assessed after $5 \mathrm{~d}$ and no further deaths occurred subsequently.

Statistical analysis. Data in Figs. 1 and 2 represent mean \pm SD. For data analysis, a one-way ANOVA followed by Duncan's post-hoc test were performed. $P=0.05$ was considered significant. In Figs. 3 and 4 real data points are shown. For detection of significant differences between groups a nonparametric Kruskal-Wallis one-way ANOVA was used. $P<0.05$ was considered significant. In case of a significant difference between groups, a Mann-Whitney U-Wilcoxon rank sum $w$ test was used to test significance between two groups. To compare survival data in Fig. 5, a Kaplan-Meyer test was performed using log rank statistics. Significance levels of Figs. 1-5 were as stated in the figure legends. All statistical calculations were performed using the SPSS 6.0 software for windows (SPSS Inc., Chicago, IL).

\section{Results}

LBP-dependent stimulation of RAW 264.7 cells by LPS. To investigate the activity of $\mathrm{mLBP}$, the murine macrophage cell line RAW 264.7 was stimulated with various concentrations of LPS in the presence of increasing quantities of mLBP. Stimulation of RAW 264.7 cells with E. coli O111:B4 LPS at concentrations $\leq 3 \mathrm{ng} / \mathrm{ml}$ was clearly LBP-dependent (Fig. 1). LBP at concentrations up to $1 \mu \mathrm{g} / \mathrm{ml}$ corresponding to normal LBP concentrations present in murine serum was able to increase $\mathrm{TNF}-\alpha$ synthesis. In contrast, when LBP concentrations were further increased to $10 \mu \mathrm{g} / \mathrm{ml}$ corresponding to serum levels during the in vivo acute phase reaction in mice, LPS-induced TNF- $\alpha$ response was clearly inhibited as compared with TNF- $\alpha$ levels measured in the presence of $0.1 \mu \mathrm{g} / \mathrm{ml}$ of LBP. Toxicity tests, i.e., trypan blue exclusion and release of $\mathrm{LDH}$ indicating cytolysis, revealed that maximum mLBP concentrations used $(10 \mu \mathrm{g} / \mathrm{ml})$ failed to display any toxicity towards RAW 264.7 cells (Table I). Additionally, PMA-mediated TNF- $\alpha$ synthesis was not substantially impaired by high mLBP concentrations.

Synergistic inhibition of LPS effects in vitro by LBP and serum. In the presence of $1 \%$ murine serum, $330 \mathrm{pg} / \mathrm{ml}$ LPS stimulated RAW 264.7 cells to secrete $1.8 \mathrm{ng} / \mathrm{ml}$ TNF- $\alpha$ (Fig. 2). $1 \%$ serum corresponding to $15 \mathrm{ng} / \mathrm{ml}$ native $\mathrm{mLBP}$ gave

Table I. Lack of Cytotoxicity of High Concentrations of mLBP $(10 \mu \mathrm{g} / \mathrm{ml})$ Towards RAW 264.7 Cells

\begin{tabular}{lcc}
\hline & \multicolumn{2}{c}{$\mathrm{mLBP}$ concentration } \\
\cline { 2 - 3 } & $0 \mu \mathrm{g} / \mathrm{ml}$ & $10 \mu \mathrm{g} / \mathrm{ml}$ \\
\hline Toxicity (\% dead cells)* evaluated by & & \\
Trypan blue exclusion & $<1$ & $<1$ \\
LDH release & 0.31 & 0.39 \\
TNF- $\alpha$ synthesis $(\mathrm{ng} / \mathrm{ml})^{\ddagger}$ & 0.62 & 0.55
\end{tabular}

*Incubation was carried out in the presence of $330 \mathrm{pg} / \mathrm{ml}$ E. coli O111: $B 4 \mathrm{LPS}$ or ${ }^{\ddagger} 50 \mathrm{ng} / \mathrm{ml}$ PMA in RPMI for $4 \mathrm{~h}$ at $37^{\circ} \mathrm{C}$.

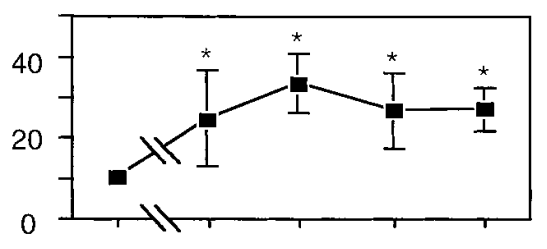

LPS

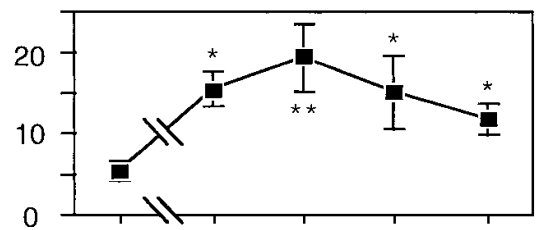

$3 \mathrm{ng} / \mathrm{ml}$

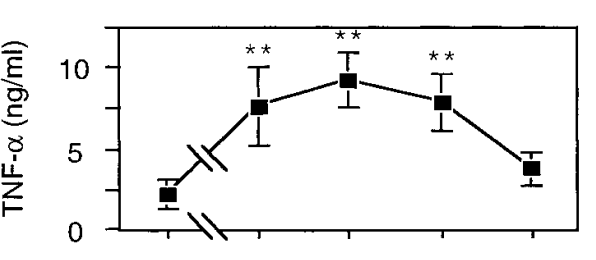

$1 \mathrm{ng} / \mathrm{ml}$
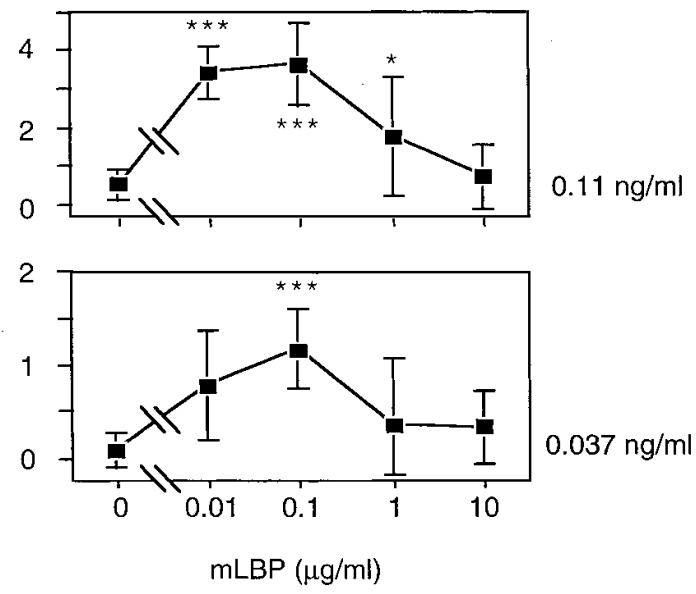

Figure 1. LBP-dependent stimulation of RAW 264.7 cells. RAW 264.7 cells were stimulated with $E$. coli O111:B4 LPS and increasing concentrations of recombinant $\mathrm{mLBP}$, as indicated, in serum-free RPMI medium for $4 \mathrm{~h}$. Cell culture supernatants were analyzed for TNF- $\alpha$ content by ELISA. LPS concentrations decrease from top to bottom (indicated at the right side of each diagram) and inhibitory effects of mLBP can be observed only when high concentrations of mLBP and low concentrations of LPS were used. Different $x$ axis scales were used to better depict the reaction pattern. Shown are mean values of quadruplicate measurements \pm SD. *Significant differences $(P<0.05)$ to stimulation in the absence of LBP. **Significant differences $(P<0.05)$ to stimulation without LBP and with $10 \mu \mathrm{g} / \mathrm{ml}$ LBP. ***Significant differences $(P<0.05)$ to stimulation without LBP and to stimulation with 1 or $10 \mu \mathrm{g} / \mathrm{ml} \mathrm{LBP}$.

only a slightly lower signal, as compared with incubation of the cells in the presence of $1 \%$ serum and $1 \mu \mathrm{g} / \mathrm{ml}$ recombinant LBP. These results are in line with the experiments shown in Fig. 1. There, $10 \mathrm{ng} / \mathrm{ml}$ LBP induced TNF response, and increasing the LBP concentration up to $1 \mu \mathrm{g} / \mathrm{ml}$ did not lead to a further rise of TNF- $\alpha$ levels. LBP concentrations of $10 \mu \mathrm{g} / \mathrm{ml}$ in the presence of serum dramatically reduced the TNF- $\alpha$ response of RAW 264.7 cells. The signal decreased to $0.6 \mathrm{ng} / \mathrm{ml}$ TNF- $\alpha$ when $10 \mu \mathrm{g} / \mathrm{ml}$ of LBP and $1 \%$ murine serum was 


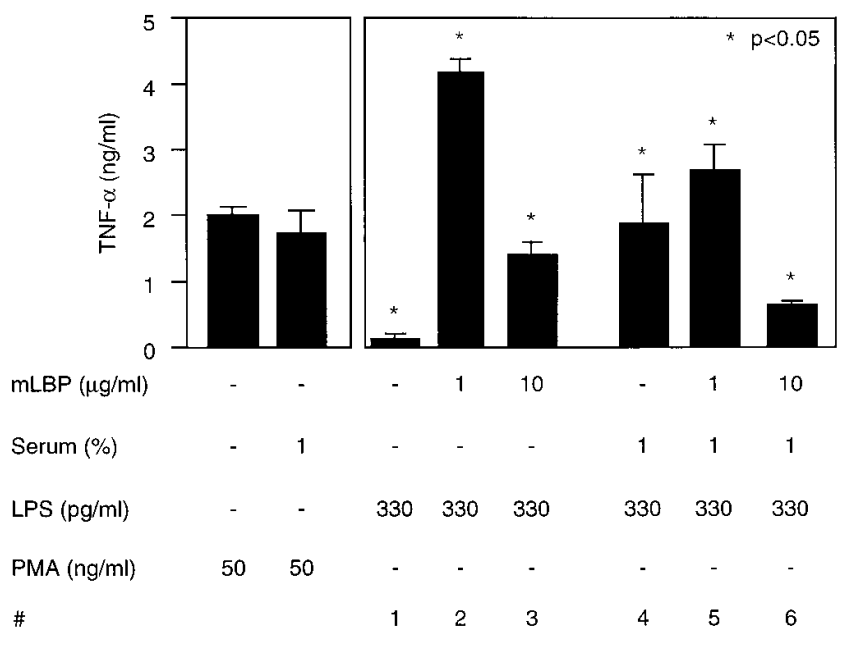

Figure 2. LBP-dependent stimulation of RAW 264.7 cells in the absence and presence of murine serum. RAW 264.7 cells were stimulated with $330 \mathrm{ng} / \mathrm{ml}$ E. coli O111:B4 LPS, and different concentrations of mLBP (right) or $50 \mathrm{ng} / \mathrm{ml} \mathrm{PMA} \mathrm{(left),} \mathrm{respectively,} \mathrm{in} \mathrm{serum-}$ free RPMI or in RPMI containing 1\% murine serum for $4 \mathrm{~h}$. Shown are mean values of quadruplicate measurements of TNF- $\alpha$ in nanograms per milliliter. *Groups 2 and 5 were significantly different $(P<$ $0.05)$ to all groups; groups 1 and 6 to all groups except to each other, group 3 to groups 1,2 , and 6 , and group 4 to group $1,2,5$, and 6 .

added. The left panel of Fig. 2 shows that cells stimulated with $50 \mathrm{ng} / \mathrm{ml} \mathrm{PMA}$ in the presence and absence of $1 \%$ murine serum secrete similar quantities of TNF- $\alpha$.

$L B P$ serum concentrations in D-galactosamine-sensitized mice injected with $L P S$, LPS and $m L B P$, or with $m L B P$ alone. Having observed the distinct effects of high concentrations of LBP in vitro, we were interested in determining whether recombinant mLBP can also suppress LPS-induced cytokine synthesis in vivo. For monitoring mLBP concentrations and to assess half-life of recombinant $\mathrm{mLBP}$ in vivo, mLBP serum levels during the acute phase reaction and after mLBP treatment were determined using an ELISA specific for mLBP (Fig. 3). Injection of a dose of $350 \mu \mathrm{g}$ LPS resulted in a sixfold increase in serum LBP levels from $1.5 \mu \mathrm{g} / \mathrm{ml}$ in untreated mice to $8.9 \mu \mathrm{g} / \mathrm{ml} \mathrm{LBP}$ in acute phase mouse serum (Fig. 3, right). In mice injected with small amounts of LPS (2.5 $\mathrm{ng}$ ) alone in the presence of D-galactosamine, we found LBP serum concentrations of $1.5 \mu \mathrm{g} / \mathrm{ml}$, corresponding to $\mathrm{mLBP}$ concentrations measured in untreated mice. In mice given 100 $\mu \mathrm{g}$ recombinant $\mathrm{mLBP}$ and D-galactosamine, $7.7 \mu \mathrm{g} / \mathrm{ml} \mathrm{LBP}$ were detected in the circulation $75 \mathrm{~min}$ after injection. This concentration corresponds to LBP concentrations observed during the murine acute phase and to LBP quantities, which inhibited TNF- $\alpha$ secretion of LPS-stimulated RAW 264.7 cells in vitro. When LPS and mLBP were injected simultaneously, $\mathrm{mLBP}$ levels were $6.1 \mu \mathrm{g} / \mathrm{ml}$, which is slightly below animals treated with mLBP alone and may be due to LBP-LPS interaction. After $7 \mathrm{~h}, \mathrm{LBP}$ concentrations in all three animal groups were back to baseline levels.

Influence of $m L B P$ on in vivo cytokine release and hepatic injury, indicated by ALT, in LPS-treated D-galactosamine-sensitized mice. Next, serum TNF- $\alpha$ and IL-6 levels were assessed
$75 \mathrm{~min}$ and $7 \mathrm{~h}$ after injection of LPS with or without mLBP (Fig. 4). TNF- $\alpha$ concentrations 75 min after injection of LPS alone in the presence of D-galactosamine increased from undetectable background levels to $75 \mathrm{pg} / \mathrm{ml}$ (Fig. $4 A$ ). Similarly, as seen in the in vitro cell stimulation experiments, LBP also significantly blocked the increase in TNF- $\alpha$ levels in vivo, resulting in serum levels of only $10 \mathrm{pg} / \mathrm{ml} \mathrm{TNF}-\alpha 75$ min after LPS challenge. The IL- 6 concentration measured 75 min after injection of LPS was $2,000 \mathrm{pg} / \mathrm{ml}$. In the presence of $100 \mu \mathrm{g}$ mLBP, similar to TNF- $\alpha$, only $100 \mathrm{pg} / \mathrm{ml}$ IL- 6 was measured in serum after LPS stimulation (Fig. $4 B$ ). $7 \mathrm{~h}$ after injection of LPS, levels of IL-6 decreased to nearly background concentrations. Since hepatic failure is the reason for LPS toxicity in LPS/D-galactosamine-treated mice, we studied the influence of mLBP treatment on serum concentrations of a marker enzyme for hepatic injury, ALT (36). We found elevated concentrations of ALT of $60 \mathrm{U} /$ liter $7 \mathrm{~h}$ after LPS treatment, but not at the early time point of 75 min after injection of LPS (Fig. $4 C$ ). In contrast, in serum of mice treated with LPS and $100 \mu \mathrm{g}$ $\mathrm{mLBP}$, or with mLBP alone, only $20 \mathrm{U} /$ liter, and $15 \mathrm{U} /$ liter, respectively, of ALT activity was measured.

Mortality of D-galactosamine-sensitized mice treated with LPS with or without $m L B P$. Since $\mathrm{mLBP}$ was able to decrease serum levels of proinflammatory cytokines and to inhibit liver failure as indicated by ALT serum concentrations, we were interested in determining the influence of mLBP on LPS-induced mortality in D-galactosamine-sensitized mice, as well as in an infection model using live E. coli O111:B4 bacteria. First, mice were injected with a dose of $2.5 \mathrm{ng}$ LPS per animal in combination with or without $100 \mu \mathrm{g}$ mLBP per animal. Mortality was monitored 12, 24, and $36 \mathrm{~h}$ after injection (Fig.

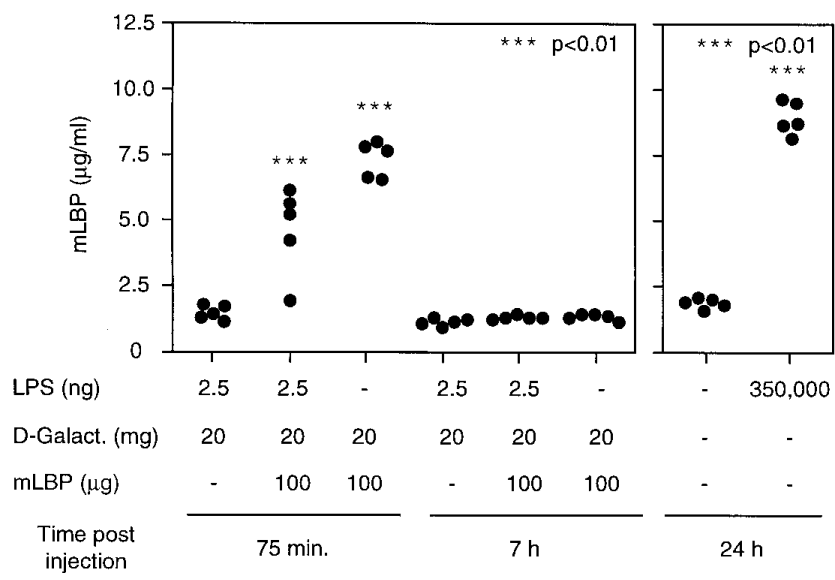

Figure 3. Serum LBP concentrations in mice injected with recombinant mLBP. C57Bl/6 mice sensitized with $20 \mathrm{mg}$ D-galactosamine were injected with $2.5 \mathrm{ng}$ E. coli O111:B4 LPS alone, LPS and $100 \mu \mathrm{g}$ $\mathrm{mLBP}$, or $100 \mu \mathrm{g} \mathrm{mLBP}$ alone ( $n=5$ per group). Shown are serum mLBP concentrations in micrograms per milliliter $75 \mathrm{~min}$ and $7 \mathrm{~h}$ after injection. As control, mice not sensitized with D-galactosamine were injected with $350 \mu \mathrm{g}$ of LPS in order to induce an acute phase response, or with PBS for determination of normal LBP levels $(n=5$ per group). Shown are real data points. (Left) Differences between groups at the 75 -min time point were significant $(P=0.002)$ whereas differences at the 7-h time point were not $(P=0.06)$. ***Significant differences to the LPS/D-gal group $(P<0.01)$ at the 75 -min time point. 
A

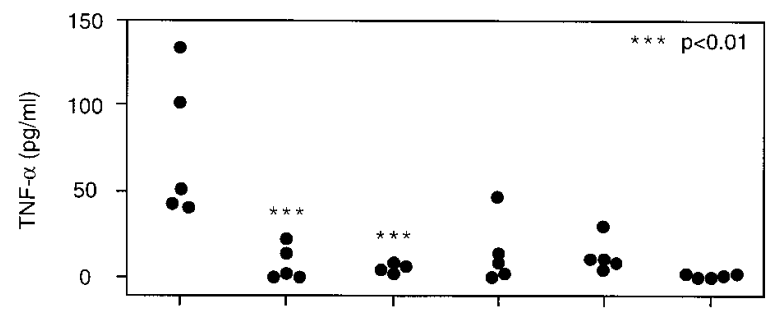

B

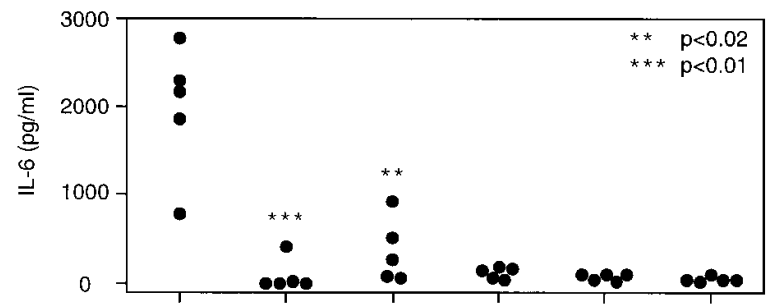

C

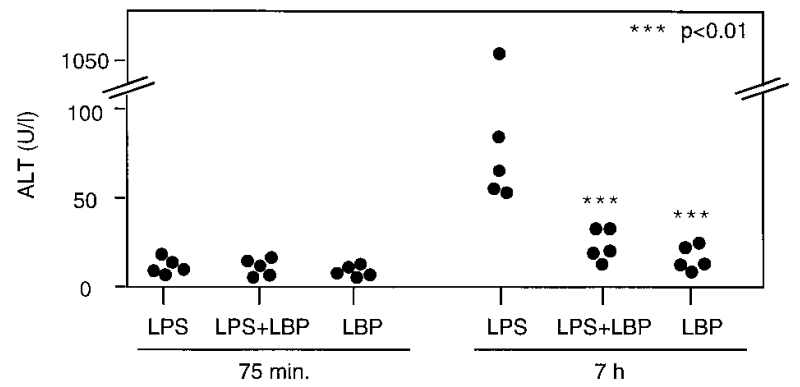

Figure 4. In vivo induction of TNF- $\alpha$, IL-6, and ALT in D-galactosamine-sensitized mice. C57Bl $/ 6$ mice sensitized with $20 \mathrm{mg}$ D-galactosamine were injected with $2.5 \mathrm{ng}$ E. coli O111:B4 LPS alone, LPS and $100 \mu \mathrm{g} \mathrm{mLBP}$, or $\mathrm{mLBP}$ alone ( $n=5$ per group). Shown are serum TNF- $\alpha(A)$ and IL-6 levels $(B)$ in picograms per milliliter and ALT $(C)$ in units per liter as real data points $75 \mathrm{~min}$ and $7 \mathrm{~h}$ after injection, assessed by ELISA ( $A$ and $B$ ) or enzymatic activity assay $(C)$. Differences between groups were significant at the time point $75 \mathrm{~min}$ in $A(P=0.009)$ and $B(P=0.005)$, and at the 7 -h time point in $A$ $(P=0.034)$ and $C(P=0.008)$. **Significant differences to the LPS group $(P<0.02)$. *** Significant differences to the LPS group $(P<0.01)$.

5). After 12 h, 12 out of 20 mice treated with LPS had died, whereas only 5 out of 20 animals treated with LPS and mLBP had died. Within a further 12-h observation period, only one animal in each group died and at $36 \mathrm{~h}$ after injection of LPS with or without mLBP, $35 \%$ of the mice treated with LPS, but $70 \%$ of the mice treated with LPS and mLBP had survived. Additionally, in an infection model animals treated with $10^{7}$ live $E$. coli and $100 \mu \mathrm{g}$ mLBP had a fourfold higher survival rate, as compared with animals injected with $E$. coli and a control buffer. 8 out of 19 mice treated with bacteria and mLBP survived for a period of $5 \mathrm{~d}$, whereas only 2 out of 19 animals treated with bacteria alone survived (Table II). No further deaths occurred subsequently.

\section{Discussion}

Since the release of proinflammatory cytokines is thought to be a pathogenic element in sepsis, it has remained unclear why the host releases large quantities of LBP, thereby further en-

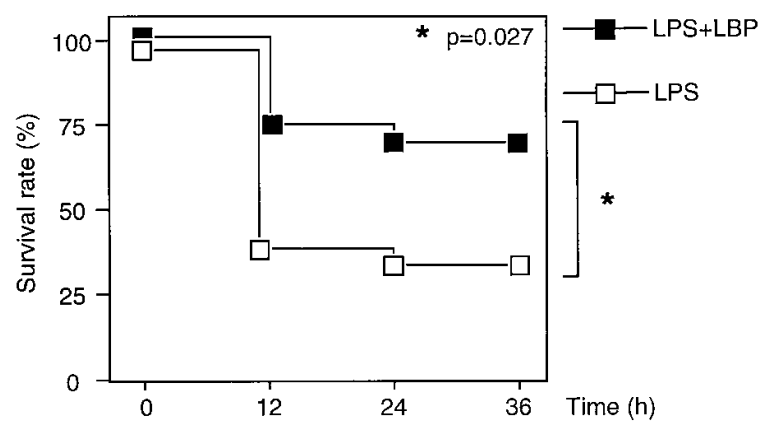

Figure 5. Mortality of D-galactosamine-sensitized mice injected with LPS with or without mLBP. C57Bl/6 mice sensitized with $20 \mathrm{mg}$ D-galactosamine were injected with $2.5 \mathrm{ng}$ E. coli O111:B4 LPS alone, or LPS and $100 \mu \mathrm{g}$ recombinant $\operatorname{mLBP}(n=20$ per group). Mortality was monitored 12,24 , and $36 \mathrm{~h}$ after injection. Statistics were performed using the Kaplan-Meyer test. *Statistical significance (log rank) between LPS-treated and LPS and LBP-treated groups was 0.027 .

hancing LPS-induced cytokine secretion. Our results show that high levels of LBP, as seen during the acute phase response in vivo, inhibit LPS effects both in vitro and in vivo and protect mice from bacterial challenge. RAW 264.7, a CD14-positive murine macrophage cell line, secretes high quantities of TNF- $\alpha$ in response to LPS even in the absence of serum proteins (37). For lower LPS concentrations ( $\leq 1 \mathrm{ng} / \mathrm{ml}$ ), however, representing more closely the clinical sepsis situation, stimulation of RAW 264.7 cells is LBP dependent, as we show here. This LBP dependency is of a bipolar nature. Addition of mLBP at concentrations up to $1 \mu \mathrm{g} / \mathrm{ml}$, corresponding to constitutive mLBP levels, resulted in an increased secretion of TNF- $\alpha$ in vitro. High concentrations of LBP $(10 \mu \mathrm{g} / \mathrm{ml})$, simulating the acute phase rise of LBP, however, resulted in a clearly decreased TNF- $\alpha$ response, as compared with the TNF- $\alpha$ response in the presence of $0.1 \mu \mathrm{g} / \mathrm{ml} \mathrm{LBP}$. Intraperitoneal injection of mLBP in vivo also was able to inhibit LPS-mediated secretion of cytokines in D-galactosamine-sensitized mice. LBP concentrations leading to an in vivo blockade of LPS effects were similar to those observed during the murine acute phase and to those inhibiting TNF- $\alpha$ secretion in vitro. However, the inhibitory effect of mLBP towards LPS was limited to the peritoneal space and was not observed when LPS or LBP was injected intravenously (data not shown). Lipoproteins, associated with LBP (18) or LPS in serum, could be responsible for this discrepancy of LBP activity in serum versus the peritoneal cavity.

Table II. Mortality of Mice Injected with Live E. coli O111:B4 with or without $m L B P$

\begin{tabular}{cc}
\hline Treatment* & Mice (survived/total) \\
\hline $10^{7}$ E. coli O111:B4 + 100 $\mu \mathrm{g} \mathrm{mLBP}$ & $8 / 19$ \\
$10^{7}$ E. coli O111:B4 + control buffer & $2 / 19$ \\
\hline
\end{tabular}

* C57Bl/6 mice were injected with live E. coli O111:B4 bacteria $\left(10^{7}\right)$ and $100 \mu \mathrm{g} \mathrm{mLBP}$, or with bacteria and control buffer, respectively. Survival was assessed after $5 \mathrm{~d}$. 
It is known that the lethal effects of LPS in mice sensitized with D-galactosamine are due to hepatotoxic effects of LPSinduced cytokines like TNF- $\alpha(38,39)$. Intraperitoneal injection of $\mathrm{mLBP}$ in our experiments blocked the rise in cytokine levels, prevented liver damage, and also reduced LPS-mediated mortality significantly. These results seem to be in contrast to results of Gallay et al. who found a decreased mortality in LPS/D-galactosamine-treated mice if they were treated with a polyclonal anti-mLBP antibody $(40,41)$. However, treatment with this antibody did not lead to in vivo LBP depletion but may have enhanced LPS clearance involving Fc-mediated clearance of LPS-LBP antibody immune complexes. Our results and those from others using LBP-deficient mice are concordant with the results presented here. LPS-induced cytokine release was absent in vivo and in whole blood obtained from LBP-deficient animals $(33,34)$ corresponding to our in vitro data where low concentrations of LPS in the absence of mLBP failed to induce TNF- $\alpha$. Furthermore, in an intraperitoneal Salmonella infection model, a reduced survival rate in LBPdeficient mice indicating a protective role of LBP was observed (33). This result complements our finding of LBP protection against an intraperitoneal $E$. coli infection, as shown in Table II.

A somehow similar bipolar nature of biologic activity has been described for another protein involved in LPS recognition, CD14. In vitro, intermediate concentrations of soluble CD14 increased the LBP-dependent stimulation of neutrophils, whereas high concentrations of soluble CD14 inhibited it (42). CD14-deficient mice are resistant (43), and transgenic mice expressing human CD14 are sensitized to LPS (44). On the other hand, administration of high doses of recombinant soluble CD14 has a protective effect towards the toxic properties of LPS (45). LBP and soluble CD14 in vivo both seem to protect from LPS toxicity and bacteremia if elevated, although both proteins in vitro seem to contribute to LPS recognition and LPS-mediated cell stimulation. Furthermore, our in vivo results are in line with recent studies indicating inhibitory effects of high concentrations of human LBP in vitro (46-48).

The results reported here for the first time show a protective role of LBP in an intraperitoneal murine sepsis model. The mechanism of how mLBP protects mice from LPS-induced sepsis and bacteremia currently is not clear. It has been described that LBP in vivo is associated with HDL (18) and that LBP increases LPS transfer into HDL, resulting in a protective effect towards LPS toxicity $(18,31,32)$. However, LPS blocking activity of high concentrations of mLBP in the absence of serum (and HDL), observed by us, indicates that this may not be the only explanation for the inhibitory activity of mLBP. Another potential mechanism for LBP-mediated protection could be an enhanced clearance of LPS from the circulation. However, Jack et al. failed to detect any difference in LPS clearance in LBP-deficient mice as compared with heterozygous animals (33). A mechanism for improving survival of bacterial infection could be the ability of LBP to enhance CD14dependent phagocytic uptake of bacteria $(28,29)$. However, we found high concentrations of mLBP reducing uptake of bacteria in vitro as compared with uptake of bacteria in the presence of low LBP concentrations (data not shown), ruling out that enhanced phagocytosis is the major mechanism for protection against bacteremia by LBP. Our in vitro data imply that the LPS/LBP ratio is critical for the cellular reaction pattern of the host, confirming recent reports of others (49). LPS- dependent interaction of LBP with immobilized HDL has also been found recently to depend on the ratio of LPS and LBP (50). In human sepsis serum, LPS levels are in the nanogram per milliliter range, whereas acute phase levels of LBP approach $100 \mu \mathrm{g} / \mathrm{ml}$. Therefore, a molar ratio of LPS/LBP of 1:10,000 may occur during sepsis in humans. Normal mice are very resistant to LPS. Only in D-galactosamine-sensitized mice can a similar LPS/LBP ratio be achieved, enabling the finding of inhibitory activity of LBP (reported here). One recent report and our own unpublished results showed that persisting high LBP levels in sepsis patients are correlated with a poor prognosis (51). However, these results do not prove that high levels of LBP are part of the pathophysiology of sepsis and thus are a cause of death. On the contrary, high levels of LBP may also reflect an upregulated defense mechanism that fails to overcome sepsis successfully.

We conclude that acute phase levels of mLBP suppress LPS-induced cytokine release and mortality in a murine intraperitoneal sepsis model and may be a physiologic defense mechanism of the host against endotoxemia. Despite the limitations of murine sepsis models, the results presented here may point furthermore to a potential use of recombinant LBP as a therapeutic intervention strategy in sepsis, using a natural defense mechanism of the host against overstimulation by bacterial products. For any clinical application of LBP, however, further investigation on the exact timing and dosing regimen in order to exhibit a protective role of LBP is needed.

\section{Acknowledgments}

We thank Dr. J. Weber for his generous help with statistical analysis. The excellent technical assistance of F. Creutzburg and N. Siegemund is acknowledged. Furthermore, we are grateful to Drs. D. Golenbock (Boston, MA), R.J. Ulevitch (La Jolla, CA), and S.D. Wright (Rahway, NJ) for critical reading of the manuscript.

This work was supported by the Deutsche Forschungsgemeinschaft (grant Schu 828/1-4), and the Bundesministerium für Bildung, Wissenschaft, Forschung und Technologie (grants 01KI9475 and 01KV9507/5).

\section{References}

1. Raetz, C.R., R.J. Ulevitch, S.D. Wright, C.H. Sibley, A. Ding, and C.F. Nathan. 1991. Gram-negative endotoxin: an extraordinary lipid with profound effects on eukaryotic signal transduction. FASEB (Fed. Am. Soc. Exp. Biol.) J. 5:2652-2660.

2. Ulevitch, R.J., and P.S. Tobias. 1995. Receptor-dependent mechanisms of cell stimulation by bacterial endotoxin. Annu. Rev. Immunol. 13:437-457.

3. Pajkrt, D., and S.J.H. van Deventer. 1996. The cellular response in sepsis. Curr. Top. Microbiol. Immunol. 216:119-132.

4. Glauser, M.P., G. Zanetti, J.-D. Baumgartner, and J. Cohen. 1991. Septic shock: pathogenesis. Lancet. 338:732-736.

5. Parillo, J.E. 1993. Pathogenic mechanisms of septic shock. N. Engl. J. Med. 328:1471-1477.

6. Dellinger, R.P., S.M. Opal, D. Rotrosen, A.F. Suffredini, J.L. Zimmerman, R.C. Bone, C.H. Bosken, P. Dellinger, R.A. Goldstein, S. Hurd, et al. 1997. From the bench to the bedside: the future of sepsis research. Chest. 111: 744-753.

7. Morrison, D.C., and J.L. Ryan. 1987. Endotoxin and disease mechanisms. Annu. Rev. Med. 38:417-432.

8. Raetz, C.R.H. 1990. Biochemistry of endotoxins. Annu. Rev. Biochem. 59:129-170.

9. Lynn, W.A., and D.T. Golenbock. 1992. Lipopolysaccharide antagonists. Immunol. Today. 13:271-276.

10. Rietschel, E.T., H. Brade, O. Holst, L. Brade, L.S. Müller, U. Mamat, U. Zähringer, F. Beckmann, U. Seydel, K. Brandenburg, et al. 1996. Bacterial endotoxin: chemical constitution, biological recognition, host response, and immunological detoxification. Curr. Top. Microbiol. Immunol. 216:39-81.

11. Alexander, J.W., S.T. Boyce, and J.K. Roche. 1990. The process of mi- 
crobial translocation. Ann. Surg. 212:496-510.

12. Tobias, P.S., K. Soldau, and R.J. Ulevitch. 1986. Isolation of a lipopolysaccharide-binding acute phase reactant from rabbit serum. J. Exp. Med. 164:777-793.

13. Lamping, N., A. Hoess, B. Yu, T.C. Park, C.J. Kirschning, D. Pfeil, D. Reuter, S.D. Wright, F. Herrmann, and R.R. Schumann. 1996. Effects of site directed mutagenesis of basic residues (Arg 94, Lys 95, Lys 99) of lipopolysaccharide (LPS) binding protein on binding and transfer of LPS and subsequent immune cell activation. J. Immunol. 157:4648-4656.

14. Wright, S.D., R.A. Ramos, P.S. Tobias, R.J. Ulevitch, and J.C. Mathison. 1990. CD14, a receptor for complexes of lipopolysaccharide (LPS) and LPS binding protein. Science. 249:1431-1433.

15. Hailman, E., H.S. Lichenstein, M.M. Wurfel, D.S. Miller, D.A. Johnson, M. Kelley, L.B. Busse, M.M. Zukowski, and S.D. Wright. 1994. Lipopolysaccharide (LPS)-binding protein accelerates the binding of LPS to CD14. J. Exp. Med. 179:269-277.

16. Tobias, P.S., K. Soldau, J.A. Gegner, D. Mintz, and R.J. Ulevitch. 1995. Lipopolysaccharide binding protein-mediated complexation of lipopolysaccharide with soluble CD14. J. Biol. Chem. 270:10482-10488.

17. Yu, B., and S.D. Wright. 1996. Catalytic properties of lipopolysaccharide (LPS) binding protein (LBP). Transfer of LPS to soluble CD14. J. Biol. Chem. 271:4100-4105.

18. Wurfel, M.M., S.T. Kunitake, H. Lichenstein, J.P. Kane, and S.D. Wright. 1994. Lipopolysaccharide (LPS)-binding protein is carried on lipoproteins and acts as a cofactor in the neutralization of LPS. J. Exp. Med. 180:10251035 .

19. Schumann, R.R., S.R. Leong, G.W. Flaggs, P.W. Gray, S.D. Wright, J.C. Mathison, P.S. Tobias, and R.J. Ulevitch. 1990. Structure and function of lipopolysaccharide binding protein. Science. 249:1429-1431.

20. Mathison, J.C., P.S. Tobias, E. Wolfson, and R.J. Ulevitch. 1992. Plasma lipopolysaccharide (LPS)-binding protein. A key component in macrophage recognition of gram-negative LPS. J. Immunol. 149:200-206.

21. Calvano, S.E., W.A. Thompson, M.N. Marra, S.M. Coyle, H.F. de Riesthal, R.K. Trousdale, P.S. Barie, R.W. Scott, L.L. Moldawer, and S.F. Lowry. 1994. Changes in polymorphonuclear leukocyte surface and plasma bactericidal/permeability-increasing protein and plasma lipopolysaccharide binding protein during endotoxemia or sepsis. Arch. Surg. 129:220-226.

22. Gallay, P., C. Barras, P.S. Tobias, T. Calandra, M.P. Glauser, and D. Heumann. 1994. Lipopolysaccharide (LPS)-binding protein in human serum determines the tumor necrosis factor response of monocytes to LPS. J. Infect. Dis. 170:1319-1322.

23. Froon, A.H., M.A. Dentener, J.W. Greve, G. Ramsay, and W.A. Buurman. 1995. Lipopolysaccharide toxicity-regulating proteins in bacteremia. J. Infect. Dis. 171:1250-1257.

24. Schumann, R.R., C.J. Kirschning, A. Unbehaun, H. Aberle, H.-P. Knopf, N. Lamping, R.J. Ulevitch, and F. Herrmann. 1996. The lipopolysaccharide-binding protein is a secretory class 1 acute-phase protein whose gene is transcriptionally activated by APRF/STAT-3 and other cytokine-inducible nuclear proteins. Mol. Cell. Biol. 16:3490-3503.

25. Opal, S.M., J.E. Palardy, M.N. Marra, C.J. Fisher, Jr., B.M. McKelligon, and R.W. Scott. 1994. Relative concentrations of endotoxin-binding proteins in body fluids during infection. Lancet. 344:429-431.

26. Schäfer, K., R.R. Schumann, S. Stöteknuel, J. Bohler, J. Schollmeyer, and G.J. Dobos. 1997. Lipopolysaccharide binding protein: a marker for intraperitoneal bacterial infection in patients with CAPD peritonitis. Adv. Perit. Dial. 13:210-213.

27. Gegner, J.A., R.J. Ulevitch, and P.S. Tobias. 1995. Lipopolysaccharide (LPS) signal transduction and clearance. Dual roles for LPS binding protein and membrane CD14. J. Biol. Chem. 270:5320-5325.

28. Grunwald, U., X.L. Fan, R.S. Jack, G. Workalemahu, A. Kallies, F. Stelter, and C. Schütt. 1996. Monocytes can phagocytose gram negative bacteria by a CD14 dependent mechanism. J. Immunol. 157:4119-4125.

29. Lengacher, S., C.V. Jongeneel, D. Le Roy, J.D. Lee, V. Kravchenko, R.J. Ulevitch, M.P. Glauser, and D. Heumann. 1996. Reactivity of murine and human recombinant LPS binding protein (LBP) with LPS and gram negative bacteria. J. Inflamm. 47:165-172.

30. Ulevitch, R.J., A.R. Johnston, and D.B. Weinstein. 1979. New function for high density lipoproteins: their participation in intravascular reactions of bacterial lipopolysaccharides (LPS). J. Clin. Invest. 64:1516-1524.

31. Levine, D.M., T.S. Parker, T.M. Donnelly, A. Walsh, and A.L. Rubin. 1993. In vivo protection against endotoxin by plasma high density lipoprotein.
Proc. Natl. Acad. Sci. USA. 90:12040-12044.

32. Pajkrt, D., J.E. Doran, F. Koster, P.G. Lerch, B. Arnet, T. van der Poll, J.W. ten Cate, and S.J.H. van Deventer. 1996. Antiinflammatory effects of reconstituted high-density lipoprotein during human endotoxemia. J. Exp. Med. 185:1601-1608.

33. Jack, R.S., X. Fan, M. Bernheiden, G. Rune, M. Ehlers, A. Weber, G. Kirsch, R. Mentel, B. Fürll, M. Freudenberg, et al. 1997. Lipopolysaccharidebinding protein is required to combat a murine Gram-negative bacterial infection. Nature. 389:742-745.

34. Wurfel, M.M., B.G. Monks, R.R. Ingalls, R.L. Dedrick, R. Delude, D. Zhou, N. Lamping, R.R. Schumann, R. Thieringer, M.J. Fenton, et al. 1997. Targeted deletion of the LBP gene leads to profound suppression of LPS responses ex vivo while in vivo responses remain intact. J. Exp. Med. 186:20512056.

35. Lottenberg, R., U. Christensen, C.M. Jackson, and P.L. Coleman. 1981. Assay of coagulation proteases using peptide chromogenic and fluorogenic substrates. Methods Enzymol. 80:342-361.

36. Szabó, C., G.J. Southan, and C. Thiemermann. 1994. Beneficial effects and improved survival rodent models of septic shock with $S$-methylisothiourea sulfate, a potent and selective inhibitor of inducible nitric oxide synthase. Proc. Natl. Acad. Sci. USA. 91:12472-12476.

37. Beutler, B., J. Mahoney, T.N. Le, P. Pekala, and A. Cerami. 1985. Purification of cachectin, a lipoprotein lipase-suppressing hormone secreted by endotoxin-induced RAW 264.7 cells. J. Exp. Med. 161:984-995.

38. Galanos, C., M.A. Freudenberg, and W. Reutter. 1979. Galactosamineinduced sensitization to the lethal effects of endotoxin. Proc. Natl. Acad. Sci. USA. 76:5939-5943.

39. Lehmann, V., M.A. Freudenberg, and C. Galanos. 1987. Lethal toxicity of lipopolysaccharide and tumor necrosis factor in normal and D-galactosamine-treated mice. J. Exp. Med. 165:657-663.

40. Gallay, P., D. Heumann, D. Le Roy, C. Barras, and M.P. Glauser. 1993. Lipopolysaccharide-binding protein as a major plasma protein responsible for endotoxemic shock. Proc. Natl. Acad. Sci. USA. 90:9935-9938.

41. Gallay, P., D. Heumann, D. Le Roy, C. Barras, and M.P. Glauser. 1994 Mode of action of anti-lipopolysaccharide binding protein antibodies for prevention of endotoxemic shock in mice. Proc. Natl. Acad. Sci. USA. 91:79227926.

42. Hailman, E., T. Vasselon, M. Kelley, L.A. Busse, M.C. Hu, H.S. Lichenstein, P.A. Detmers, and S.D. Wright. 1996. Stimulation of macrophages and neutrophils by complexes of lipopolysaccharide and soluble CD14. J. Immunol. $156: 4384-4390$

43. Haziot, A., E. Ferrero, F. Kontgen, N. Hijiya, S. Yamamoto, J. Silver, C.L. Stewart, and S.M. Goyert. 1996. Resistance to endotoxin shock and reduced dissemination of gram negative bacteria in CD14 deficient mice. Immunity. 4:407-414.

44. Ferrero, E., D. Jiao, B.Z. Tsuberi, L. Tesio, G.W. Rong, A. Haziot, and S.M. Goyert. 1993. Transgenic mice expressing human CD14 are hypersensitive to lipopolysaccharide. Proc. Natl. Acad. Sci. USA. 90:2380-2384.

45. Haziot, A., G.W. Rong, X.Y. Lin, J. Silver, and S.M. Goyert. 1995. Recombinant soluble CD14 prevents mortality in mice treated with endotoxin (lipopolysaccharide). J. Immunol. 154:6529-6532.

46. Abrahamson, S.L., H.M. Wu, R.E. Williams, K. Der, N. Ottah, R. Little, H. Gazzano-Santoro, G. Theofan, R. Bauer, S. Leigh, et al. 1997. Biochemical characterization of recombinant fusions of lipopolysaccharide binding protein and bactericidal/permeability increasing protein: implications in biological activity. J. Biol. Chem. 272:2149-2155.

47. Amura, C.R., L.-C. Chen, N. Hirohashi, M.-G. Lei, and D.C. Morrison. 1997. Two functionally independent pathways for lipopolysaccharide-dependent activation of mouse peritoneal macrophages. J. Immunol. 159:5079-5083.

48. Troelstra, A., B.N. Giepmans, K.P. van Kessel, H.S. Lichenstein, J. Verhoef, and J.A. van Strijp. 1997. Dual effects of soluble CD14 on LPS priming of neutrophils. J. Leukocyte Biol. 61:173-178.

49. Tobias, P.S., K. Soldau, N.M. Iovine, P. Elsbach, and J. Weiss. 1997. Lipopolysaccharide (LPS) binding proteins BPI and LBP form different types of complexes with LPS. J. Biol. Chem. 272:18682-18685.

50. Massamiri, T., P.S. Tobias, and L.K. Curtiss. 1997. Structural determinants for the interaction of lipopolysaccharide binding protein with purified high density lipoproteins: role of apolipoprotein A-I. J. Lipid. Res. 38:516-525.

51. Carroll, S.F., R.L. Dedrick, and M.L. White. 1997. Plasma levels of lipopolysaccharide binding protein (LBP) correlate with outcome in sepsis and other patients. Shock. 8:101. (Abstr.) 